\title{
ANTIMICROBIAl ACTIVITY AND High THERMOSTABILITY OF A NOVEL BLIS SECRETED BY ENTEROCOCCUS MUNDTII ISOLATED FROM LEBANESE COW'S MILK
}

Imad AL Kassaa ${ }^{1,2}$, Nancy Safourim ${ }^{1}$, Nancy Mostafa ${ }^{1}$ and Monzer Hamze ${ }^{1,2}$ ${ }^{1}$ Health and Environmental Microbiology Laboratory (LMSE), EDST/FSP-Lebanese University, Tripoli-Lebanon

${ }^{2}$ Faculty of Public Health (FSP) section III, Lebanese University, Tripoli- Lebanon mhamze@monzerhamze.com

(Received 15 December 2015 - Accepted 28 September 2016)

\section{ABSTRACT}

AL Kassaa, I., Safourim, N., Mostafa, N. and Hamze, M. Antimicrobial activity and high thermostability of a novel BLIS secreted by Enterococcus Mundtii isolated from lebanese cow's milk. 2016. Lebanese Science Journal, 17(2): 166-176.

Lactic acid bacteria (LAB) are used in many fields such as fermentation agents, increasing nutritional value and improving organoleptic quality of food. Also they are used as probiotics and preservatives against pathogens and spoilage microbes by producing antimicrobial substances such as bacteriocins. Fifty cow's milk samples were collected and 175 LAB isolates were isolated and identified by using biochemical method. Fifteen isolates showed an antimicrobial activity against Listeria monocytogenes ATCC ${ }^{\circledR} 19115^{\mathrm{TM}}$. One strain, BL4 which showed the strongest activity, was chosen to extract and characterize its antimicrobial substance in order to evaluate its potential use as a new food protective agent. This strain was identified as Enterococcus mundtii by pyrosequencing method. The active substance was extracted using solvent method. This Bacteriocin like Inhibitory Substances "BLIS" can support a high temperature $\left(121^{\circ} \mathrm{C}\right)$ for a long time and resist $\mathrm{pH}$ variation. The BLIS BL4 can be considered as a peptide active against many food pathogen and food-spoilage microbes, such as Listeria monocytogenes and Penicillium spp. BLIS BLA can be used in food application as bio-preservative to reduce food-spoilage and food-borne diseases in food products.

Keywords: lactic acid bacteria, bacteriocin, BLIS, enterococcus, cow's milk

\section{INTRODUCTION}

The new life style in food sector imposes on the agribusiness industries to increase the production of ready to eat food or frozen food, imposing to keep this type of food in good conditions and away from spoilage and pathogenic microbes.

http://dx.doi.org/10.22453/LSJ-017.2.166176

National Council for Scientific Research - Lebanon 2016@

1sj.cnrs.edu.lb/vol-17-no-2-2016/ 
Unfortunately, the chemical products used for conserving food have a lot of side effects on human health. Carcinogenic, teratogenic, allergic and high toxic effects are the most important problems of these chemical additives (Ross et al., 2002). Because of these consequences, the idea of bio-preservation was born. The concept of bio-preservation of food is using bioactive agent such as microorganisms and/or their own substances to conserve food in a natural way. This would preserve the organoleptic characteristics and nutritional properties of food usually lost after using chemical agents (Kassaa et al., 2015; Settanni and Corsetti, 2008).

LAB bacteriocins are antimicrobial peptides synthesized and secreted by many genus and species of bacteria. Besides bacteriocins, secondary metabolites are also secreted to inhibit the growth of competitive bacterial strains (Drider et al., 2006; Hwanhlem et al., 2013; Kjos et al., 2010). Most of bacteriocins are small peptide, have a net positive charge at neutral or slightly acidic $\mathrm{pH}$, amphiphilic in nature and vary in spectrum and mode of activities. Bacteriocins also display different molecular structures and molecular weights; they are stable at high pH and thermal conditions (Kassaa et al., 2015; Nes et al., 1996; Zacharof and Lovitt, 2012)

Currently, the production of bacteriocin by enterococci is studied extensively due to their GRAS (Generally Recognized As Safe) status (Fernández et al., 2007; Javed et al., 2011), since they prevent the growth of many food-borne pathogens and spoilage bacteria such as Staphylococcus aureus (S. aureus), Listeria monocytogenes (L. monocytogenes), Escherichia coli (E. coli) and Pseudomonas spp. They can also be used in different food products in order to enhance their shelf life (Javed et al., 2011).

This study reports the isolation of LAB from Lebanese cow's milk. A screening of the antimicrobial activity of isolated LAB was realized and followed by extraction and characterization of the bacteriocin or BLIS produced by Enterococcus mundtii (E. mundtii) BL4. This substance showed high thermostability and can be used as potential bio-control agent against food borne pathogens and food spoilage microbes.

\section{MATERIALS AND METHODS}

\section{Sampling and LAB isolation}

Fifty samples of healthy cow's milk were collected from farms in North Lebanon, and then the samples were transported in sterile tubes to LMSE laboratory under $4{ }^{\circ} \mathrm{C}$ condition. LAB were isolated from samples, by direct plating on MRS agar (Scharlau-Spain). A $10 \%(\mathrm{w} / \mathrm{v})$ food sample in diluent $[0.1 \%(\mathrm{w} / \mathrm{v})$ peptone] was homogenized and 10 -fold serially diluted. Plates of serial dilution $\left(10^{-3}\right)$ in MRS were incubated for $48 \mathrm{~h}$ at $30^{\circ} \mathrm{C}$ in $5 \%$ $\mathrm{CO}_{2}$ condition. From each plate, 3 suspected colonies were picked up and re-cultured on a new plate to be conserved with $10 \%$ glycerol MRS broth at $-80{ }^{\circ} \mathrm{C}$.

\section{Identification of active LAB}

The LAB strains showing an anti-listerial activity were identified using biochemical and molecular methods. The RAPID STR ${ }^{\circledR}$ (Remel, UK) was used as biochemical method followed by API 50 CHL (Biomérieux-France) kit to confirm the identification of BL4 strain. The test protocol was done as mentioned in the kit manual. The pyrosequencing was used as a 
molecular identification by sequencing the V1 and V2 region of $16 \mathrm{~S}$ rDNA gene of active strains. The pyrosequencing protocol was realized according to (Al Kassaa et al., 2014).

\section{Antimicrobial activity of isolated LAB by agar well diffusion assay}

$50 \mathrm{~mL}$ of Muller Hinton (MH) soft agar (1\% agar, w/v) was seeded with $500 \mu \mathrm{L}$ of a suspension of $10^{8} \mathrm{CFU} / \mathrm{ml}$ (0.5 Mac-Ferland) of L. monocytogenes ATCC ${ }^{\circledR} 19115^{\mathrm{TM}}$ (used as indicator strain) and then mixed. The mixture was poured into a sterile Petri dish, and after setting of agar, wells of $5 \mathrm{~mm}$ in diameter were formed. Two-fold serial dilutions of supernatant were made in $40 \mathrm{mM}$ potassium phosphate buffer $(\mathrm{pH}$ 7) and aliquots of $50 \mu 1$ from each dilution were placed in wells in agar plates seeded with the indicator strain. Plates were incubated for $24 \mathrm{~h}$ at the optimum temperature of indicator strains as shown in Table 2 (Ogunbanwo et al., 2003; Schillinger and Lücke, 1989). The antimicrobial activity was defined according to the zone of inhibition on the lawn of sensitive cells of indicator strains.

\section{Bacterial strains and growth conditions of BL4}

Enterococcus mundtii BL4 (E. mundtii), was grown at $37^{\circ} \mathrm{C}$ in de Man, Rogosa and Sharpe (MRS) medium (Scharlau-Spain) for 18-24 h. L. monocytogenes ATCC $\left(19115^{\mathrm{TM}}\right.$ was used as indicator strain to determine its activity in all characterization steps.

\section{Characterization of the crude active antimicrobial substance}

\section{i) Effect of temperature on crude BLIS BL4}

The thermostability of BLIS BL4 was tested by heating $500 \mu 1$ of the supernatant at $95^{\circ} \mathrm{C}$ for $5 \mathrm{~min}$. After cooling, the anti-listerial activity was assayed by agar well diffusion assay.

\section{ii) Effect of enzymes on crude BLIS BL4 activity}

One $\mathrm{mL}$ of supernatant was mixed with $150 \mu \mathrm{l}$ of each enzyme solution ( $\alpha$ chymotrypsin $(10 \mathrm{mg} / \mathrm{ml})$, proteinase $\mathrm{K}(20 \mathrm{mg} / \mathrm{ml})$ and trypsin $(10 \mathrm{mg} / \mathrm{ml})$ ) purchased from Sigma-aldrich (Germany). The mixtures were then incubated at $37{ }^{\circ} \mathrm{C}$ for $2 \mathrm{~h}$. The $\mathrm{pH}$ of all samples was readjusted to 7.0. Then all treated supernatants were heated for $5 \mathrm{~min}$ at $95^{\circ} \mathrm{C}$ and put directly in ice to inhibit activity of proteolytic enzymes.

\section{Extraction of BLIS BL4}

\section{i) Extraction of adsorbed BLIS BL4 from producer cells}

For extraction of BLIS BL4, the Yang method was followed as described before (Yang et al., 1992). Briefly, the producer strain, E. mundtii BL4, was grown to early stationary phase in $500 \mathrm{~mL}$ of MRS nutrient broth. The culture broth was adjusted to $\mathrm{pH}$ 7. Then it was heated to $70^{\circ} \mathrm{C}$ for $20 \mathrm{~min}$ to kill the cells which were harvested by centrifugation at $6,000 \mathrm{rpm}$ for $20 \mathrm{~min}$. After the cells had been washed with $5 \mathrm{mM}$ sodium phosphate (pH 6.5), they were resuspended in $25 \mathrm{ml}$ of $100 \mathrm{mM} \mathrm{NaCl}$ at $\mathrm{pH} 2.0$ (adjusted with $5 \%$ phosphoric acid) and mixed with a magnetic stirrer for $30 \mathrm{~min}$ at $4^{\circ} \mathrm{C}$. Cell suspensions were then centrifuged at $6,000 \mathrm{rpm}$ 
for $45 \mathrm{~min}$. The supernatants were collected and dialyzed in 1,000-molecular-weight-cutoff dialysis bags against $\mathrm{H}_{2} \mathrm{O}$ at $4^{\circ} \mathrm{C}$ for 24 hours. The BLIS activity was defined according to the zone of inhibition by agar well diffusion assay.

\section{ii) Extraction of BLIS BL4 using organic solvent method (chloroform)}

$500 \mathrm{~mL}$ of nutrient MRS broth were seeded with $E$. mundtii BL4 and incubated at $37^{\circ} \mathrm{C}$ for 24 hours. The sample was centrifuged at $6,000 \mathrm{rpm}$ for $20 \mathrm{~min}$ and the supernatant was collected. The culture supernatant $(490 \mathrm{ml})$ was stirred vigorously with chloroform $(500 \mathrm{ml})$ and transferred in a separating funnel. The interface layer between the aqueous and organic phase, which contain bacteriocin was harvested, and the residual chloroform was eliminated by speed vacuum (Mezaini et al., 2009).

\section{iii) The activity assay of BLIS BL4}

The BLIS BL4 was serially diluted (1:2, 1:4, 1:8, etc.) by mixing $500 \mu 1$ of supernatant and $500 \mu \mathrm{l}$ of MRS broth. The activity was assayed against L. monocytogenes CMUL 004 by agar well diffusion assay. Then the activity units (AU) per milliliter were calculated (Saraniya and Jeevaratnam, 2014).

\section{BLIS characterization}

\section{i) Storage and thermostability of BLIS BL4}

The effect of temperature on BLIS stability was determined by keeping aliquots of extracted BLIS for 1 day, 1 week and 6 weeks in sterile tubes at $4^{\circ} \mathrm{C}$. On the other hand, $500 \mu \mathrm{l}$ of extracted BLIS were incubated at 35,50 and $100{ }^{\circ} \mathrm{C}$ in temperature-controlled water bath for 0,15 and $30 \mathrm{~min}$, and at $121^{\circ} \mathrm{C}$ by autoclaving for 15 and $30 \mathrm{~min}$. The $\mathrm{pH}$ was readjusted back to 7.0 and antilisterial activity was assayed using agar well diffusion assay.

\section{ii) Stability of BLIS BL4 under pH conditions}

The effect of $\mathrm{pH}$ was determined by adjusting the $\mathrm{pH}$ of BLIS BL4 solution in the range $2-12$ by adding $1 \mathrm{M} \mathrm{HCL}$ (acidic $\mathrm{pH}$ ) and $2 \mathrm{M} \mathrm{NaOH}$ (alkaline $\mathrm{pH}$ ). The samples were then incubated at $25^{\circ} \mathrm{C}$ for $2 \mathrm{~h}$, the $\mathrm{pH}$ was readjusted back to 7.0 and BLIS BL4 anti-listerial activity was assayed using agar well diffusion assay.

\section{iii) Cytotoxicity effect}

In order to determine the cytotoxicity of the extracted BLIS, a preliminary test was performed using blood agar as described before to evaluate the hemolytic effect of BLIS BL4 and its produced strain (DeMaria and Lye, 1999).

\section{Antimicrobial spectrum determination}

The antibacterial activity spectrum of the extracted BLIS BL4 was assessed against food-borne pathogens and food spoilage bacteria obtained from "Collection Microbiologique 
de l' Université Libanaise (CMUL)" (Table 2) by agar well diffusion assay. For bacterial indicator strains, the same protocol aforementioned was followed, whilst for fungal indicator strains another methodology was realized. Briefly, a few conidia (without mycelium) were taken from culture plate and then poured in $0.9 \% \mathrm{NaCl}$ suspension. After dilution, the conidia concentration was determined by using a cell counter under microscope. Once the suspension was ready $\left(10^{6}\right.$ conidia/ml), a sterile swab was immersed in suspension and then the excess was removed by pressing the swab at the edges. Finally, the culture medium was inoculated with this swab by spreading three times on the three plate zones.

\section{RESULTS AND DISCUSSION}

The aim of this study was the isolation and characterization of the first bacteriocinogenic LAB strain "E. mundtii BL4" isolated in Lebanon. E. mundtii BL4 will be evaluated for their capacities to control food-spoilage and food-borne pathogens in food products, in order to enhance food shelf life.

From 50 cow's milk samples, 175 strains were isolated and evaluated for an eventual antimicrobial activity. The preliminary identification of the fifteen active strains was based on morphologic and biochemical characteristics. First, as results of biochemical identification using RapID ${ }^{\mathrm{TM}}$ STR (Remel, UK), the active strains were identified as four Lactococcus spp, four Pediococcus pentasaceus, two Streptococcus sanguinis, two E. mundtii, two Weissella confuse, and one Gemella morbillorum. The gallery API 50 CHL (BioMerieux, France) was performed to confirm the biochemical identification of Lactococcus spp BL4 which showed the strongest activity. The API 50 CHL (BioMerieux, Frane) result showed that BL4 strain was identified as Lactococcus lactis. According to Al Kassaa et al., (2014), the biochemical identification of LAB is not efficient and therefore molecular methods are needed. The variable region V1 and V2 of 16S rDNA gene of BL4 were pyrosequenced. The results showed that BL4 was identified as E. mundtii by pyrosequencing. Several studies have showed that the pyrosequencing was more reliable especially for LAB strains (Al Kassaa et al., 2014).

The antimicrobial activity of these different strains was tested by agar well diffusion assay. The experimental conditions eliminate the influence of lactic acid and hydrogen peroxide. This is why L. monocytogenes was chosen as a target strain (Al Kassaa et al., 2014). This bacterium has the ability to tolerate lactic acid and produces catalase as a protective agent against hydrogen peroxide.

The results of this assay showed that only fifteen strains of the total $175 \mathrm{LAB}$ isolates had an antimicrobial activity against $L$. monocytogenes. Their inhibition zone diameters against L. monocytogenes vary between 8 and $20 \mathrm{~mm}$. The low number of active strains was similar to another study realized by Toit et al., when they found only seven active strains among 92 isolates (7.6\%) (Toit et al., 2000). Another study showed that one active strain was isolated of 77 isolates $(1.29 \%$ ) (Jennes et al., 2000). Several studies have showed the capacity of LAB to inhibit the growth of certain strains of L. monocytogenes (Allende et al., 2007). This bacterium is responsible of severe diseases transmitted by food with high percentage of fatality (20 to 30\%) (Ramaswamy et al., 2007).

E. mundtii BL4 isolate showed the strongest anti-listerial activity $(20 \mathrm{~mm})$ and was chosen to characterize its antimicrobial substances. The Enterococcus genus plays an important role in cheese production (Franz et al., 1999). The bacteriocins secreted by Enterococcus spp., 
named recently enterocins, have shown an antibacterial activity against Listeria spp. and Clostridium spp. (Giraffa, 1995). Protease sensitivity assay demonstrated that BLIS BL4 activity was largely impaired by treatment with $\alpha$-chymotrypsin, proteinase $\mathrm{K}$ and trypsin. This protease treatment confirmed that the active substance is a peptide or protein. In addition, this substance is stable under high temperature. These preliminary characterizations reveal that this inhibitory substance is probably "BLIS" or "Bacteriocin" and must be demonstrated (Hwanhlem et al., 2014; Toit et al., 2000).

These features are similar to those of bacteriocins produced by Enterococcus strains isolated from pig feces (Toit et al., 2000). They were inactivated by $\alpha$-chymotrypsin, proteinase $\mathrm{K}$, trypsin, pronase, pepsin and papain, but not by lipase, lysozyme and catalase. These bacteriocins were heat stable (Toit et al., 2000).

\section{Extraction of bacteriocin or BLIS}

In this context, BLIS BL4 was extracted using two methods: extraction of adsorbed bacteriocin from producer cells, and extraction using an organic solvent (chloroform). The organic solvent method showed more satisfying results. The other technique, adsorptiondesorption, could serve as an alternative to purify this BLIS (Yang et al., 1992). This method is more economical and faster than other classic methods (Piard et al., 1992). Unfortunately, this method depends on producer strain and on the nature of bacteriocin or BLIS itself (Yang et al., 1992). The activities of extracted BLIS BL4 as well as the extraction yield are shown in Table 1.

\section{TABLE 1}

Summary of the Extraction Profile of Bacteriocin from Culture Supernatant of E. Mundtii BL4

\begin{tabular}{|c|c|c|c|}
\hline Extraction method & Volume $(\mathrm{ml})$ & Bacteriocin activity $(\mathrm{AU} / \mathrm{ml})$ & Yield $(\%)$ \\
\hline Crude & 100 & 840 & 100 \\
Adsorption/desorption & 10 & 112 & 13.3 \\
Chloroform & 10 & 280 & 33.3 \\
\hline
\end{tabular}

\section{BLIS characterization}

Extracted BLIS BL4 maintained full activity after 6 weeks of storage at $4^{\circ} \mathrm{C}$. Also this substance was heat-stable to $35^{\circ} \mathrm{C}, 50^{\circ} \mathrm{C}, 100^{\circ} \mathrm{C}$ and $121^{\circ} \mathrm{C}$ for $30 \mathrm{~min}$. In a similar study, Grande et al., (2005) studied the stability of enterocin AS-48 for fruit and vegetable juices biopreservation. They found that the solutions of enterocin AS-48 in sterile distilled water were stable for 120 days at 4 to $28{ }^{\circ} \mathrm{C}$ (Grande et al., 2005). Hwanhlem et al., (2013) reported that the storage of bacteriocin at low temperature allowed long storage periods. However, optimum temperature and time of storage depend on bacteriocin type (Hwanhlem et al., 2013). 
BLIS BL4 was found active and stable over a wide range of $\mathrm{pH}$ from 2 to 9 (Figure 1). Solichová et al., (2012) characterized an anti-Listeria bacteriocin-like substance produced by $E$. mundtii. This bacteriocin-like substance is heat-stable to $100{ }^{\circ} \mathrm{C}$ at $30 \mathrm{~min}$; it is also stable in a wide range of $\mathrm{pH}$ value 2-10 (Solichová et al., 2012). In another study, partially purified bacteriocin produced by E. faecium 130 isolated from mozzarella cheese was stable at $\mathrm{pH}$ ranging from 2 to 10 with no loss of activity after heating at $100{ }^{\circ} \mathrm{C}$ for $15 \mathrm{~min}$ (Tulini et al., 2011).

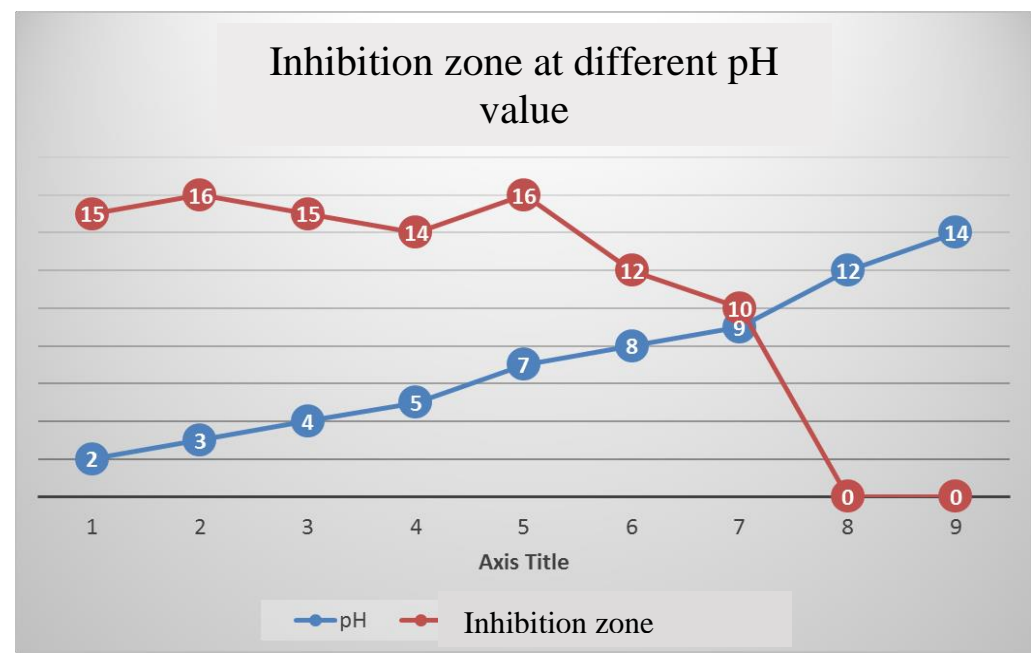

Figure 1. pH stability of BL4 BLIS measured by inhibition zone (mm)

This result confirms the possibility of using BLIS BL4 in food industry as conservative agent, especially food which needs heat and acidic treatment.

On the other hand, BLIS BL4 showed low hemolytic effect but Enterococcus mundtii BL4 had none. This effect is not necessarily caused by BLIS BL4 but due to action of impurities in the extract. So it is essential to perform total purification and then the hemolytic test could be performed. The use of Enterococcus genus in food is not comfortable yet. The opportunistic species like E. faecium and E. faecalis are not "GRAS" (De Vuyst et al., 2003). For this reason, E. mundtii was chosen as the representative of bacteriocins producing enterococcus due to their potential safety in food (Jennes et al., 2000).

\section{Antimicrobial spectrum of bacteriocin}

The antimicrobial spectrum of BLIS BL 4 was evaluated by the agar well diffusion assay. The bacteriocin exhibited a good spectrum of inhibition. When BLIS BL4 was tested against 17 indicator strains, 5 strains were found sensitive (Table 2). Most of the sensitive strains were Gram-positive bacteria especially L. monocytogenes CMUL 004. Table 2 shows the indicator strains which were susceptible to BLIS BL4 and the value of inhibition zone diameters. This indicates that BLIS BL4 could be a suitable biopreservative to increase the safety and extending the storage life of various food products especially after evaluation of its GRAS characteristics. 
A study reported that Enterocin LR/6, a purified bacteriocin, exhibited a broad inhibitory spectrum against some food-borne pathogens comprising both Gram-positive and Gram negative such as L. monocytogenes, Pseudomonas aeruginosa, Aeromonas spp., Yersinia enterocolitica, Bacillus licheniformis and Shigella spp. as well as against several strains of LAB (Kumar and Srivastava, 2009).

Moreover, the results obtained in the present study agree well with those of previous studies indicating that some strains of $\mathrm{LAB}$, isolated from Forest of mangrove (water, soil, leaves, fruits...etc.), have a broad spectrum of activity against strains of $L$. monocytogenes but inactive against some strains of E. coli (Hwanhlem et al., 2014).

TABLE 2

Different Strains Tested to Determine the Antibacterial Activity Spectrum of the Extracted BLIS

\begin{tabular}{|c|c|c|c|}
\hline Tested strains & $\begin{array}{l}\text { Culture media used in well } \\
\text { diffusion method }\end{array}$ & $\begin{array}{l}\text { Incubation } \\
\text { temperature and time }\end{array}$ & $\begin{array}{l}\text { Inhibition zone } \\
\text { (mm) }\end{array}$ \\
\hline Streptocoque bovis CMUL 425 & Muller-Hinton & $35^{\circ} \mathrm{C}, 18 \mathrm{hrs}$ & 11 \\
\hline Enterococcus feacalis CMUL 624 & Muller-Hinton & $35^{\circ} \mathrm{C}, 18 \mathrm{hrs}$ & 12 \\
\hline Enterococcus faecium CMUL 613 & Muller-Hinton & $35^{\circ} \mathrm{C}, 18 \mathrm{hrs}$ & 13 \\
\hline Staphylococcus areus CMUL 520 & Muller-Hinton & $35^{\circ} \mathrm{C}, 18 \mathrm{hrs}$ & 0 \\
\hline Bacillus cereus ATCC 11778 CMUL 141 & Muller-Hinton & $35^{\circ} \mathrm{C}, 18 \mathrm{hrs}$ & 0 \\
\hline Clostridium perfrengens CMUL IX 002 & Muller-Hinton $+5 \%$ blood & $35^{\circ} \mathrm{C}, 20 \mathrm{hrs}$ & 0 \\
\hline Escherichia coli (EPEC) CMUL 578 & Muller-Hinton & $35^{\circ} \mathrm{C}, 18 \mathrm{hrs}$ & 0 \\
\hline Salmonella typhi CMUL 232 & Muller-Hinton & $35^{\circ} \mathrm{C}, 18 \mathrm{hrs}$ & 0 \\
\hline Shigella spp CMUL 049 & Muller-Hinton & $35^{\circ} \mathrm{C}, 18 \mathrm{hrs}$ & 0 \\
\hline Brucella spp CMUL 031 & Muller-Hinton $+5 \%$ blood & $35^{\circ} \mathrm{C}, 20 \mathrm{hrs}$ & 0 \\
\hline Campylobacter jejuni CMUL Ax 016 & $\begin{array}{l}\text { Muller-Hinton }+5 \% \text { blood }+ \\
\text { NAD }\end{array}$ & $35^{\circ} \mathrm{C}, 24 \mathrm{hrs}$ & 0 \\
\hline Listeria monocytogenes CMUL AL 004 & Muller-Hinton $+5 \%$ blood & $35^{\circ} \mathrm{C}, 20 \mathrm{hrs}$ & 19 \\
\hline Lactobacillus acidophilus CMUL 011 & Man, Rogosa and Sharp & $30^{\circ} \mathrm{C}, 24 \mathrm{hrs}$ & 0 \\
\hline Lactobacillus brevis CMUL 024 & Man, Rogosa and Sharp & $30^{\circ} \mathrm{C}, 24 \mathrm{hrs}$ & 0 \\
\hline Pseudomonas aeruginosa CMUL 297 & Muller-Hinton & $35^{\circ} \mathrm{C}, 18 \mathrm{hrs}$ & 0 \\
\hline Penicillium spp CMUL 127 & Sabouraud + Choloramphenicol & $20^{\circ} \mathrm{C}, 5$ days & 10 \\
\hline Aspergillus flavus CMUL 051 & Sabouraud + Choloramphenicol & $20^{\circ} \mathrm{C}, 5$ days & 0 \\
\hline Candida albicans CMUL 032 & Sabouraud + Choloramphenicol & $35^{\circ} \mathrm{C}, 18 \mathrm{hrs}$ & 0 \\
\hline
\end{tabular}


$\mathrm{LAB}$ use the production of bacteriocin as a defense system against other bacteria that come into competition for food. This is mainly produced during period of stress (Riley and Chavan, 2007). Under the conditions of our work at the laboratory, LAB isolates are in monoculture and in excess of nutrients so the production of bacteriocin seems to be pointless for them. This hypothesis could explain why among 175 isolates, only 15 had a positive activity.

A study demonstrated that the production of bacteriocin is related to the producer strain, incubation time, final $\mathrm{pH}$ of the culture media, etc. Stressful conditions could have been set for isolates in order to collect a large amount of antimicrobial peptides as reported by several studies (Hwanhlem et al., 2014; Pal and Ramana, 2010; Saraniya and Jeevaratnam, 2014; Yang et al., 1992).

\section{CONCLUSION}

The BLIS BL4 exhibit a good spectrum activity against many indicator strains. As BLIS BL4 can be active under high temperature and acidic $\mathrm{pH}$ conditions, it can be used in food sector as a natural preservative to inhibit several food-borne pathogens and food spoilage microbes such as Penicillium spp, and to prevent the transmission of L. monocytogenes to vulnerable population. A cytotoxicity assay should be realized on pure BLIS BL4 in order to ensure its safety use. In addition, cation exchange Liquid Chromatography and Mass Spectrometry will be realized to totally purify BLIS BL4 and to determine its molecular weight.

\section{ACKNOWLEDGMENT}

The authors express their thanks to Mr. Taha ABDOU and Ms Mariam YEHIA, for their excellent assistance during this study.

\section{REFERENCES}

Al Kassaa, I., Hamze, M., Hober, D., Chihib, N.-E., and Drider, D. 2014. Identification of vaginal lactobacilli with potential probiotic properties isolated from women in North Lebanon. Microb. Ecol., 67: 722-734.

Allende, A., Martínez, B., Selma, V., Gil, M.I., Suárez, J.E., and Rodríguez, A. 2007. Growth and bacteriocin production by lactic acid bacteria in vegetable broth and their effectiveness at reducing Listeria monocytogenes in vitro and in fresh-cut lettuce. Food Microbiol., 24: 759-766.

De Vuyst, L., Foulquié Moreno, M.R., and Revets, H. 2003. Screening for enterocins and detection of hemolysin and vancomycin resistance in enterococci of different origins. Int. J. Food Microbiol., 84: 299-318.

DeMaria, L., and Lye, D.J. 1999. Detection of bacterial cytotoxic activities from waterdamaged ceiling tile material following incubation on blood agar. J. Ind. Microbiol. Biotechnol., 23: 653-655.

Drider, D., Fimland, G., Héchard, Y., McMullen, L.M., and Prévost, H. 2006. The Continuing Story of Class IIa Bacteriocins. Microbiol. Mol. Biol. Rev., 70: 564.

Fernández, M., Martínez-Bueno, M., Martín, M.C., Valdivia, E., and Maqueda, M. 2007. Heterologous expression of enterocin AS-48 in several strains of lactic acid bacteria. J. Appl. Microbiol., 102: 1350-1361.

Franz, C.M.A.P., Holzapfel, W.H., and Stiles, M.E. 1999. Enterococci at the crossroads of food safety. Int. J. Food Microbiol., 47: 1-24. 
Giraffa, G. 1995. Enterococcal bacteriocins: their potential as anti-Listeria factors in dairy technology. Food Microbiol., 12: 291-299.

Grande, M.J., Lucas, R., Valdivia, E., Abriouel, H., Maqueda, M., Omar, N.B., MartínezCañamero, M., and Gálvezi, A. 2005. Stability of enterocin AS-48 in fruit and vegetable juices. J. Food Prot., 68: 2085-2094.

Hwanhlem, N., Biscola, V., El-Ghaish, S., Jaffrès, E., Dousset, X., Haertlé, T., H-Kittikun, A., and Chobert, J.-M. 2013. Bacteriocin-Producing Lactic Acid Bacteria Isolated from Mangrove Forests in Southern Thailand as Potential Bio-Control Agents: Purification and Characterization of Bacteriocin Produced by Lactococcus lactis subsp. lactis KT2W2L. Probiotics Antimicrob. Proteins, 5: 264-278.

Hwanhlem, N., Chobert, J.-M., and H-Kittikun, A. 2014. Bacteriocin-producing lactic acid bacteria isolated from mangrove forests in southern Thailand as potential bio-control agents in food: Isolation, screening and optimization. Food Control, 41: 202-211.

Javed, A., Masud, T., Ain, Q. ul, Imran, M., and Maqsood, S. 2011. Enterocins of Enterococcus faecium, emerging natural food preservatives. Ann. Microbiol., 61: 699-708.

Jennes, W., Dicks, L. M. T., and Verwoerd, D. J. 2000. Enterocin 012, a bacteriocin produced by Enterococcus gallinarum isolated from the intestinal tract of ostrich. J. Appl. Microbiol.

Kassaa, I.A., Belguesmia, Y., Chihib, N.-E., Hamze, M., Bendali, F., Naghmouchi, K., Fliss, I., and Drider, D. 2015. Applications des bacteriocines et bactéries lactiques dans le contrôle des pathogènes alimentaires. In: Sécurité sanitaire des aliments, (Paris: Economica), pp. 231-258.

Kjos, M., Snipen, L., Salehian, Z., Nes, I.F., and Diep, D.B. 2010. The Abi Proteins and Their Involvement in Bacteriocin Self-Immunity. J. Bacteriol., 192: 2068.

Kumar, M., and Srivastava, S. 2009. Antilisterial Activity of a Broad-Spectrum Bacteriocin, Enterocin LR/6 from Enterococcus faecium LR/6. Appl. Biochem. Biotechnol., 162: 698-706.

Mezaini, A., Chihib, N.-E., Bouras, A.D., Nedjar-Arroume, N., and Hornez, J.P. 2009. Antibacterial activity of some lactic acid bacteria isolated from an Algerian dairy product. J. Environ. Public Health, 678-495.

Nes, I.F., Diep, D.B., Håvarstein, L.S., Brurberg, M.B., Eijsink, V., and Holo, H. 1996. Biosynthesis of bacteriocins in lactic acid bacteria. Antonie Van Leeuwenhoek, 70: $113-128$.

Ogunbanwo, S.T., Sanni, A.I., and Onilude, A.A. 2003. Characterization of bacteriocin produced by Lactobacillus plantarum F1 and Lactobacillus brevis OG1. Afr. J. Biotechnol., 2: 219-227.

Pal, A., and Ramana, K. v. 2010. Purification and Characterization of Bacteriocin from Weissella Paramesenteroides Dfr-8, an Isolate from Cucumber (cucumis Sativus). $J$. Food Biochem., 34: 932-948.

Piard, J.C., Muriana, P.M., Desmazeaud, M.J., and Klaenhammer, T.R. 1992. Purification and Partial Characterization of Lacticin 481, a Lanthionine-Containing Bacteriocin Produced by Lactococcus lactis subsp. lactis CNRZ 481. Appl. Environ. Microbiol., 58: 279-284.

Ramaswamy, V., Cresence, V.M., Rejitha, J.S., Lekshmi, M.U., Dharsana, K.S., Prasad, S.P., and Vijila, H.M. 2007. Listeria--review of epidemiology and pathogenesis. $J$. Microbiol. Immunol. Infect. Wei Mian Yu Gan Ran Za Zhi., 40: 4-13.

Riley, M.A., and Chavan, M.A. 2007. Bacteriocins. Springer-Verlag, New York, Berlin, Heidelberg. 
Ross, R.P., Morgan, S., and Hill, C. 2002. Preservation and fermentation: past, present and future. Int. J. Food Microbiol., 79: 3-16.

Saraniya, A., and Jeevaratnam, K. 2014. Optimization of nutritional and non--nutritional factors involved for production of antimicrobial compounds from Lactobacillus pentosus SJ65 using response surface methodology. Braz. J. Microbiol. Publ. Braz. Soc. Microbiol., 45: 81-88.

Schillinger, U., and Lücke, F.K. 1989. Antibacterial activity of Lactobacillus sake isolated from meat. Appl. Environ. Microbiol., 55: 1901-1906.

Settanni, L., and Corsetti, A. 2008. Application of bacteriocins in vegetable food biopreservation. Int. J. Food Microbiol., 121: 123-138.

Solichová, K., Složilová, I., Jebavá, I., Uhrová, B., and Plocková, M. 2012. Characterisation of Antilisterial Bacteriocin-Like Substance Produced by Enterococcus mundtii. Czech J. Food Sci., 30: 89-97.

Toit, M.D., Franz, C.M. a. P., Dicks, L.M.T., and Holzapfel, W.H. 2000. Preliminary characterization of bacteriocins produced by Enterococcus faecium and Enterococcus faecalis isolated from pig faeces. J. Appl. Microbiol., 88: 482-494.

Tulini, F.L., Gomes, B.C., and De Martinis, E.C.P. 2011. Partial purification and characterization of a bacteriocin produced by Enterococcus faecium 130 isolated from mozzarella cheese. Food Sci. Technol. Camp., 31: 155-159.

Yang, R., Johnson, M.C., and Ray, B. 1992. Novel method to extract large amounts of bacteriocins from lactic acid bacteria. Appl. Environ. Microbiol. 58, 3355-3359.

Zacharof, M.P., and Lovitt, R.W. 2012. Bacteriocins produced by Lactic Acid Bacteria: a Review Article. APCBEE Procedia, 2: 50-56. 